\title{
THE APPLICATION OF WEB-QUEST TECHNOLOGY AT TEACHING FILOLOGICAL DISCIPLINES
}

\section{Natalia Kuzmenko ${ }^{1}$ Natalia Valuyeva ${ }^{2}$}

\author{
DOI: https://doi.org/10.30525/978-9934-588-11-2_42
}

Modern education is faced with the task of finding new types and forms of educational activities organization. Teaching should develop independent critical and creative thinking and promote self-study. To this end, many teachers have long been using project technology engaging Internet resources. But the large amount of information on the network and its quality not only simplifies the process of work on the project, but also complicates it. One of the possible solutions is Web Quest technology. In addition, the use of this technology can help students to form their personal learning environment.

It is worth considering the theoretical study of Web Quest technology, the prospects of its practical application and the possibility of using information resources of the Internet and integrating them into educational process.

Modern educational technology in universities is a scientifically grounded and normalized system of forms, methods, tools and procedures used for organizing and carrying out joint educational activities of students and teachers [1, p. 11].

Educational technology is a system of interrelated activity of teacher and students, based on a specific concept in accordance with the principles and interrelated goals, content, methods, teaching aids. Educational technologies are developed by pedagogical science and are introduced into the pedagogical practice of higher education in order to increase the efficiency of educational process, the development of professionally and socially competent personality of future specialist.

The problem of development of pedagogical technologies of higher educational institutions has been covered in the works of Ju. Babansky, V. Bespalko, P. Galperin, P. Erdniev, L. Zorina, M. Klarin, L..Land, I. Rachenko, A. Rivin, N. Talyzina and others.

Pedagogical technology is a set of means and methods of reproduction of theoretically grounded processes of education and upbringing that allows successfully to realize the set educational goals [2, p. 28]. Pedagogical technology consists of prescriptions of activity methods (didactic processes), conditions in which these activities should be embodied (organizational forms of learning), and the means of carrying out these activities.

Today, the task of any teacher is not only to equip students with modern knowledge, but also to teach students to acquire this knowledge independently, to be able to assimilate them, relying on what has already been learned, that is, to facilitate further learning. Self-motivated learning can be formed by student's personal learning

\footnotetext{
${ }^{1}$ Dniprovsk State Technical University, Ukraine

${ }^{2}$ Dniprovsk State Technical University, Ukraine
} 
environment (PLE), which consists of a number of web-based tools [3, p. 226]. Web Quest technology is used to achieve these goals, both at school and university teaching practices.

Web quest is considered to be a didactic structure within which a student's exciting search activity is planned through the Internet and other media [4]. Other researchers have classified Web quests as a separate category of educational projects - web projects $[5, \mathrm{p} .10]$. Web quest is a form of material presentation through tasking, and the solution of the tasks or answers to the questions can be obtained from various sites on the Internet. For the first time, the Web quests method was offered by American Bernie Dodge and Australian Tom March in 1995. The authors classified the tasks into the following types: Retelling task, Compilation task, Mystery task, Journalistic task, Design task, Creative product task, Consensus building task and others. This form of work is aimed at practicing not only the types of speech activity (reading, writing, listening, speaking) but also the development of communicative and speaking skills [6]. Depending on the material being researched the results of Web quest can be presented in the form of oral presentation, essays, own multimedia web pages on a given topic, composed of materials obtained during the work (texts, photos, graphics, video clips, audio materials), electronic multimedia presentations in Microsoft Power Point format. The above mentioned results can be posted on the university's website or within the university's educational network.

Typically, the work on a Web quest starts with a statement of a problem or a creation of a problem, which should motivate the student and stimulate interest in the problem. After introducing the topic, students are offered tasks that are composed by the teacher. To help organize the task the instructor can make references to print sources as well as links to sources on the Internet. All of this provides a purposeful search for the information you need. The Web quest also includes presentation of search results in the form of slides, a web page, a WORD document or any other electronic, printed or oral form. At the end of the Web quest, students are given the opportunity to critically analyze and evaluate their work, as well as evaluate the work of others [6]. The teacher can, in his turn, evaluate the students' search work. In the process of working on the Web quest, the center of knowledge is the student. The teacher ceases to be the main source of knowledge for students. He becomes the person who helps to master the acquired knowledge effectively. He formulates tasks, searches the sources and links on the Internet, performs an advisory role, creates an educational environment at which training takes place within the framework of a creative training workshop.

For philological students, the use of Web quest technology can be useful when studying disciplines of culture-oriented linguistics. For example, when studying the discipline "Culture-oriented linguistics of second foreign languages (French)», this technology can be used for seminars, practical classes or students' independent work. Applying this technology into practice, for preparation of their projects, students use authentic textual material (in French), presented on the Internet and get acquainted with the virtual socio-cultural environment of France, which increases their motivation for independent cognitive activity, develops information culture as a 
necessary component of general cultural competences of modern personality, develops the ability to think, creates an atmosphere of cooperation.

An example would be a short-term Web quest: «La cuisine française», under the theme «Culture of France».

Introduction. You are a journalist. You have been asked to prepare a material about French cuisine: its history, present times, restaurants, menus, recipes. Task. You should research this subject and tell about it to readers who would like to have an idea of French cuisine, its traditions, modern restaurants (their graduation), understanding of the menu, the ability to cook French dishes yourself. The realization process. Students should collect the information and photos to the topic; save the text and photos on the computer for final preparation; find the answers to the following points: cuisine history, cuisine of different regions of France, modern cuisine, restaurant menu, Michelin star restaurants, recipes. At the end of the study one should prepare the report and be prepared to answer the teacher and classmates questions. Information resources. Students should use the following resources to complete the task: https://fr.wikipedia.org/wiki/Cuisine_française, http://www.cuisinealafrancaise.com/fr/articles/17-histoire-de-la-cuisine; http://www. cuisine-france.com/recettes.htm; $\quad$ https://www.facebook.com/lerestaurantlaurent; http://www.foundouk.com; https://savoirs.rfi.fr/en/apprendre-enseigner/culture/lagastronomie-francaise-coup-de-feu-en-cuisine; http://www.cuisineetvinsdefrance. com/,16-recettes-de-quiches-qui-sortent-de-1-ordinaire,108884.asp; http://www.aufeminin.com/cuisine-sc4.html; http://www.marmiton.org; https://restaurant.michelin.fr/ restaurants/france. Evaluation. The criteria for evaluating the performance of the Web Quest are provided. The criteria may include following: logical presentation of the material, content of the material, language of presentation of the material, contact with the audience, originality. The final stage is the presentation of students work.

Learning, mastering and putting into practice the technology of Web-quest is extremely important because the use of information resources of the Internet and integrating them in the educational process contribute to the formation of key and subject competencies. The acquired competences encourage students to further selfdevelopment and self-education, which is the key to their further success outside the university. Web quest technology is a tool for the personal educational environment (PLE), which plays a lasting role in shaping the personality of a future specialist. All of the above factors are of real value and are prerequisites for use in further educational and professional activities of students and are one of the main reasons for high efficiency of work on Web-quest technology.

\section{References:}

1. Vdovych, S. M., \& Palka, O. V. (2013). Suchasni osvitni tekhnologiji movnoji pidgotovky majbutnikh fakhivciv sfery obslughovuvanja [Modern educational technologies of language training of sphere of service future specialists]. Kiev: Pedaghoghichna dumka. (in Ukrainian)

2. Bespaljko, V. P. (1995). Pedagogika i progressivnye tekhnologii [Pedagogy and advanced technologies]. Moscow: Izdateljstvo instituta professionaljnogo obrazovanija. (in Russian)

3. Romaniukha, M., \& Leshchenko, O. (2016). Personal learning environment in higher education. Proceedings of the $11^{\text {th }}$ International Scientific Conference on Distance Learning in 
Applied Informatics DIVAI-2016. (Slovakia, Štúrovo, May 2 - 4, 2016) (eds: Milan Turčáni, Zoltán Balogh, Michal Munk, L’ubomír Benko), Štúrovo: Wolters Kluwer, pp. 225-235.

4. Iljchenko O. V. (2012). Vykorystannja web-kvestiv u havchaljno-vykhovnomu procesi [The use of web-quests in educational process]. Osvita.ua [Education.ua] (electronic journal), Retrieved from: http://osvita.ua/school/lessons_summary/proftech/32834/(accessed 21 September 2019).

5. Matat, D. (2014). Novi tekhnologiji:veb-kvest [New technologies: web quest]. Education of Ukraine, vol. 23, pp. 10-11.

6. WebQuest.org. 2008. Available at: http://webquest.org/index.php (accessed 21 September 2019).

\title{
THEORETICAL APPROACHES TO NARRATIVE EMPATHY
}

\author{
Lyudmyla Lutsenko ${ }^{1}$ \\ Iryna Zorenko ${ }^{2}$
}

DOI: https://doi.org/10.30525/978-9934-588-11-2_43

Apart from philosophy and psychology the empathy concept has become widely used in politics, business and education. In the common lexicon it is generally understood as the capacity people have to fully comprehend the minds of others as if they were their own, whereas in academic discourse it is traditionally represented by as many as eight different meanings: «1. Knowing another person's internal state; including thoughts and feelings; 2. Adopting the posture or matching the neural responses of an observed other; 3. Coming to feel as another person feels; 4. Intuiting or projecting oneself into another's situation; 5. Imagining how another is thinking and feeling; 6. Imagining how one would think and feel in the other's place; 7. Feeling distress at witnessing another's person's suffering; 8. Feeling for another person who is suffering (empathic concern)» $[1$, p. 4-9]. On the one hand, such a variety of nuances in understanding empathy causes the problem of giving its clear, concise and unanimous definition, but at the same time it promotes an active academic interest in further exploring the empathy concept.

Translated from Greek empatheia «passion, state of emotion» and pathos «feeling»), the word «empathy» first appeared as Einfühlung in German philosophy and was associated with a number of aesthetics theorists who played a significant role in its elaboration: Johann Herbart (1776-1841) Johann Gottfried Herder (1744-1803), Karl Kostlin (1819-1894), Novalis (1772-1801), Robert Vischer (1847-1933). However, it was Theodor Lipps (1851-1913) who adjusted this concept for use in psychology for the first time. Today empathy is primarily regarded as a psychological process of «feeling what the other person feels, understanding the other from a distance (telepathy), or more generally to understandingly engage in other people's lives» $[4$, p. 20].

\footnotetext{
${ }^{1}$ Kryvyy Rih State Pedagogical University, Ukraine

${ }^{2}$ Kryvyy Rih State Pedagogical University, Ukraine 